Gocppert's and Mr. Binney's own figures. Mr. Binney's describes his new specimen as having a radiating woody cylinder, immediately within which is a second series of large ressels not arranged in radiating wedges, and which Mr. Binney says is "something like a mcdullary sheath, enclosing a medulla composed of very small and short barred tubes or utricles, in which are mingled large vascular tubes or utricles." Though this use of vague terms renders the sence obscure, I presume that Mr. Binney simply means that in the medulla of his plant a vascular cylinder cncloses a cellular medulla, or, in other words, that his specimen bus a Diploxyloid axis. That $\mathrm{Mr}$. Binney possesses a specimen having the alove structure, and giving off rootlets from its periphery, I have no reason for doubting, since in the $m \in$ moirs already quoted I have described a similar structure under the name of Diploxylon stismarioideum, and respecting which I make the following observations:- "It is possible that the plant may, like Stigmaria, prove to be the uppermost part of a root of some of the other forms" (i.c. of Lepidodendroid stems), "though I have never yet found it associated with any rootlets, and it may be a fragment from the base where stem and roots united" (loc. cit. p. 239). I arrived at the above conclusions because $I$ found in the specimen described, evidence that large rootlct bundles were given off from the woody zone as in the true Stigmaria. But I affirm that out of hundreds of Stigmarian fragments that I have examined, I have only found two possessing this structure, and I unhesitatingly express my conviction that Mr. Binney's specimen is another example of an equally rare type, both being entirely distinct from Stigmaria ficoides, to which latter plant alone is referable Mr. Binney's previously pub. lished figures, M. Goeppert's description and figures of which Mr. Binney approves, and mine which he rejects.

Mr. Binney proceeds to say: "The size of these large vascular tubes or utricles in the medulla exceeding anything so far as his knowledge extended, hitherto observed in fossil plants, shows that it was easily decomposed, and thus accounts for the general absence of the medulla in Sigillaria and its roots." To this reasoning I must altogether demur. Size has nothing whatever to do with the preservation of the tissues in fossil plants. Vascular structures strengthened by transverse bars of lignine are equally well preserved, whether they are large or small. The medulla of Stigmaria disappearerl or became much disorganised because it consisted of an unusually delicate cellular tissue with extremely thin walls. This tendency to decay was more manifest towards the centre of the medulla than at its circumference. Specimens on the table exhibit this peripheral part of the cellular medulla in exquisite perfection, giving off its characteristic cellular prolongations constituting the medullary ray $\mathrm{s}$, as described in my memoir. And yet this beantiful cellular tissue occupies the position which Mr. Binney says was occupied by "large vascular tubes or utricles." The specimens referred to showing these conditions constitute unanswerable facts.

Mr. Binney correctly notes the resemblance of the inner vascular cylinder in his specimen to his "medullary sheath." I have already said the same thing in several of my memoirs, and M. Brongniart said it before either of us. But this very homology, if correct, indicates the probability of Mr. Binney's specimen being a fragment derived from the junction of stem and root rather than a true root, since in Jiving plants possessing a medullary sheath, that sheath, as every botanist knows, is never prolonged into the true roots, for the simple physiological reason that its origin is directly connected with that of the leaf formations of the ascending axis.

$\Lambda$ s I have already observed, M. Goeppert's and Mr. Binney's previous figures represent a structure altogether different from that now described by Mr. Binney. Instead of the continuous inner vascular cylinder of the latter, $M$. Goeppert's figure displays two detached, unsymmetrically arranged, vascular bundles in the interior of the medullary cavity. I have already affirmed my conviction that these belong to intruded rootlets of a Stigmaria, and are in no respects part of the true medullary axis. On the other hand, Mr. Binney says that "they are certainly not intruded rootlets, as anyone who examines the learned author's plates can satisly himself." On this point Mr. Carruthers writes to me on Nov. 2: "No one who is accustomed to sections of Stigmaria can fail to see that Goeppert has mistaken the accidental rootlets of Stigmaria penetrating the decayed axis for an organic part of that axis." I may allow this opinion of an experienced botanist, with which I wholly concur, to neutralise that of Mr. Binney, who further says: "It is vely improbable that they" (i.e., Goeppert's vascular rootlets) "had ever been int oduced into the axis after the pith had been removed." To this I reply that it is an extremely rare thing to find any such axis which does not contain more or less of these rootlets. My cabinet is full of such examples, and in two specimens on the table, one of which has been lent me by Capt. J. Aitken, of Bacup, similar rootlets not only exist in the central axis, but have penetrated the medullary rays as in M. Goeppert's specimen.

Mr. Binney, referring to my comments upon his previous memoir, says that in "that memoir mention is only made of the large vascular bundles found in the axis, without calling them vascular or any other vessels." I do not very clearly understand what this sentence means, but I presume it is intended to imp'y that Mr. Binney never affirmed that the pith of Stigmaria contained vascular tissues, and that I have misrepresented him in stating that he had done so. I can only answer this by giving Mr. Binney's words :- " The most important circumstance thus developed is the existence of a double system of vessels in Stig. maria, first shown by Goeppert, and the consequent approach in this respect to Diplexylon, Corda. In Diploxylon, however, the inner system forms a continuous cylinder, concentric with and in juxtaposition to the wodges of wood forming the outer; while in Stigmaria the same jnner system is broken tip into scattered bundles, apparently unsymmetrically arranged in the medullary axis or pith of the plant" (Quarterly Fournal of the Geological Society, vol. xv. p. I7) ; and on p. 78 of the same memoir, describing the specimen represented by Fig. 2 , he says, "The axis is filled with eleven or twelve large vessels of circular or oval form," and the same structures are again spoken of as "vessels" no less than six times in the next seventeen lines, with the further remark that "altogether these angular vessels remind me somewhat of the vascular tissue in the middle of Anabathra" (loc. cit., p. 78). It is true that in two places Mr. Binney applies to these structures the term "utricles," by which, I presume, he means cells; but such a term, applied to such tissues, is equally applicable to all known fibro-vascular structures, and is simply equivalent to saying that scalariform vessels have no existence.

I have entered into these details because by promulgating vague and groundless doubts respecting work alrcady carefully done, Mr. Binney's communication terds to re-introduce confusion into questions that rave been virtually settled. It does this through failing to discriminate between things that differ. His introductory remarks refer to the common Stigmaria ficoides, whilst his justification of those remarks rests upon a plant of a very different character, and which $\mathrm{I}$ am absolutely certain is not the common form of Stigmaria.

\section{VEGETATION OF THE LIBYAN DESERT}

IN Dr. Ascherson's report on the vegetation of the Libyan Desert, publis hed in the botanische Zeitung, there are some interesting notes on the fall and renewal of the leaves of deciduous trees. In our climate we have little difficulty in understanding the distinction between evergreen and deciduous trees and shrubs, because the greater part of those that change their leaves cast the old ones in autumn or carly winter; and evergreens with flat leaves have them more or less coriaceous. But even with us there is a gradual transition from evergreen to deciduous through Eunonymus curopous and Ligustrum vulgare, both of which have strictly evergreen congeners in Eunony'mus japonicus and Ligustrum japonicum. Some few years ago Hoffmann started a theory that sempervirence cuuld be artificially produced, and there is no doubt that climate influences to a great extent the length of the period during which really deciduous species hold their foliage; bat it appears far more probable that these are physiological peculiarities not altogether dependent upon climate, as we find evergreen and deciduous species growing in the same regions and under precisely similar conditions. Some evergreens do not change their leaves at all, and even retain them for many years or all their lifetime; Araucaria imbricata, for example. Iaxodium distichum, one of the few deciduous Coniferæ, offers a very curious phenomenon, inasmuch as the ultimate branchlets are deciduous. The observations chronicled by Dr. Ascherson agree almost entirely with our own experience. On his outward journey be traversed $25^{\circ}$ of lat. in less than a month, which gave him an excellent opportunity for studying the conditions of the same species under very diverse climates. Thus, in the plains of Lombardy many deciduous trees, and especially Morus alba, were still partially covered with foliage on the Igth 
of November, the same species having long previously shed their leaves in Germany. In a similar manner, the fig-trees in Lower Egypt $\left(3 \mathrm{I}^{\circ} \mathrm{N}\right.$. lat. $)$ were partially clothed with foliage at the beginning of December, and in Upper Egypt $\left(27^{\circ} \mathrm{N}\right.$.) were still in full leaf, whilst already, on the $24^{\text {th }}$ of November, they were quite bare in the Apulian plain $\left(4 \mathrm{I}^{*} \mathrm{~N}\right.$.). On the rith of December, the pomegranate trees in the gardens of Siout were in yellow leaf, and on New Year's Day, 1874 , the apricot trees at larafreh were still in their prime of green leaf. Hence, one misht readily imagine that on approaching nearer the equator these same species would exhibit no interval between the fall and the renewal of the foliage, and thus, to all intents and purposes, become evergreen. But this phenomenon was only veriffed in the case of the little cultivated peach trees of the oases, in which it may not be constant. Moreover, the peach tree shows the same tendency in mild seasons with us. In the oases, at the beginning of March, when the trees began to blossom and make new growth, the old leaves were still fresh and capable of assimilation. All other deciduous trees and shrubs cultivated in the gardens of Kasr Dglrakel $\left(25^{\circ} 45^{\prime} \mathrm{N}\right.$. lat.), including the grapevine, apricot, apple, pomegranate, plum, fig, mulberry, and willow (Salix safsaf), had lost their foliage on the arrival of Dr. Ascherson, or became leafless before the end of January. It should be mentioned that the fall of the leaf in this region does not proceed with the same regularity as at home, for it is not unusual to see quite naked and fully clothed trees of the same species standing side by side. Again, the presence of abundance of moisture has the effect of enabling the trees to carry their old foliage longer and put forth their new earlier than trees growing in drier situations. And some of the willows growing by water were quite evergreen; that is, after the manner of the peach trees mentioned above. But the apricot, one of the most abundant trees, rarely retained even a few scattered old leaves on the appearance of the flowers. The same was observed of the grapevinc, fig, and mulberry. By Feb. 20 the apricot trees were in full blossom, and by March to in full foliage, so that there was only an interval of four or five weeks between the fall of the old foliage and complete development of the new. The apple and plum behaved in a similar manner, the pomegranate was a little later, the fig next in order, and finally the mulberry; whilst these same things, in the reverse sense, lost their leaves first. Frcm the preceding notes it seems that the fall and renewal of the leaf is an essential constitutional peculiarity, which is modified by climatal conditions, but not entirely subject to them. A more striking illustration of this fact may be found in exotic deciduous trees planted in Egypt. Dr. Ascherson noted more particularly the summer fall of the leaves of Poinsettia pulcherrina, a South American shrub, and Albizzic leblek, a native of the East Indies. The former is in the full sp? rescance in December, and quite leafess in April, remaining so, it is said, until the autumm. The Albizzia is extensively planted as an avenue tree. It sheds its foliage in Aprit, but soon renews it. Both of these plants lose their leaves in their uative countries during the dry, and renew them with the opening of the rainy season?

\section{SCIENTIFIC SERIALS}

Fouriut do 1'yysiqu, III., No. 34, Oct. I874.-This number commences with the frrst portion of a paver by $M$. J. Bertrand, entitied "Demonstration of Theorems rulating to Electrodynamic Actions." The object of this paper is to simplify Ampère's demonstrations of the theorems of electrodynamics. Arrangement for obtaining projections of the mctallic rays and their reversal, by M. Boudrcaux. Instead of the electric light or oxyhydrogen flame, the author employs a mixture of the chlorate of the metal with one-sixth of its weight of powdered gum-lnc. The mixture is inflamed in a carbon crucible placed in a lantern provided with a vertical slit. Reversals of the metallic lines are effected by allowing a beam of white light (Drummond or sumlight) to pass through the deflagrating mixture and analysing the resulting rays by prisms. By allowing the sun-light to fall only on one-half of the slit, the coincidence of bright with dark lines can be shown.-M. Mascart contributes a paper describing two pieces of apparatus for obtaining the phenomena of interference. -On the magnetisation of steel, by M. E. Bouty.-This number contains a translation of Lord Rayleigh's paper on the manufac ture and theory of diffraction gratings from the Philosopfical Magazine for February and March. - Sensibility of silver bro- mide to rass supposed to be chemically inactive, by $\mathrm{H}$. Vogel, from Poggendorff's Annalen.-From the same joumal there is a paper by $H$. Streintz, on changes in the length and elasticity of a wire under the influence of an electric current.-From the Proc. Roy. Soc. there are translations of Prof. Tyndall's paper on the transmission of sound, and Mr. Norman Lockyer's note on a new class of absorption phenomena.

Zeilschrift der Ocsierreichischen Gesellschaft fïr Mitoorologic. Nov. 15.-In this number Dr. Hann treats of some of the consequences of the laws of change of temperature in air undergoing change of volume. The following are some of the results of his argument, which is full of interest. The rate of cooling of ascending air varies so much with the conditions of time and place that it cannot be expressed by any general law. But both in Germany and in the tropics the mean rate lies between $0^{\circ} .5$ and $0^{\circ} \cdot 6 \mathrm{C}$. for every Ioo metres. Air warmed at the surface of the earth does not continue to rise until it reaches a level where the temperature corresponds with its own (reduced), but becomes thoroughly mixed with other strata before reaching that height. Temperature falls more rapidly with increase of height in bad than in fine weather. In a descending current there can be no condensation of moisture, and so in it the theoretical increment of $\mathrm{r}^{\circ} \mathrm{C}$. does take place. We would expect this current to clear the sky. But in fact we find that a descending current often brings rain as well as warmer weather. Our moist west winds do not bring their moisture from the tropics, but the Anti-trade, becoming warmer as it descends, collects a fresh quantity of vapour and precipilates it again when cooled by radiation or ascent of mountain slopes. The formation of hail and phenomena of hailstorms are best understood by supposing, with Reye, the lower hot moist strata to rise rapidly to a great height, not the upper air to descend, as it has been shown that this would become much warmer in descending. A cold wind blows first in the higher parts of the atmosphere, and the overheated air below rushes upward with unusual energy to a height where precipitated moisture freezes as it falls. This ascending movement of warm aix, and the further impulse given to it by liberation of the latent heat of vapour, appear to play a large part in the production and continuance of falls of rain. Dr. Hann holds the barometric minimum in the middle of a storm area to be a mechanical effect of the whirling movement of the air, and the moving force in cyclones to be the latent heat of vapour.

\section{SOCIETIES AND ACADEMIES LONDON}

Royal Society, Dec. 3.-."On tize Coefficient of Expansion of a Paraffine of high boiling-peint," by G. F. Rolwell, F.R.A.S., T.C.S., Science Master in Marlborough College. Communicated hy Prof. Stokes, Sec. R. S.

The author, after giving an accunt of his researches, concludes that paraffine is a body which undergoes a most unusual expansion in passing from its ordinary solid condition to the hich boiling-point which it possesses. He does not renember any other substance of a high boiling-point which occupies at the boiling-point a volume which is one-half as large again as the volume at the ordinary temperature. In an accompany* ing table he has introduced, side by side with the paraffine curve, the expansion curves of mercury, iodide of silver, and terbromide of phosphorus, one of the most expansible liquids known, if we except such bolies as ether, bromide of ethyl, acetate of methyl, \&c., the boiling-point of which is below $100^{\circ}$ C., and which, therefore, could not be easily introduced into the table for comparison with a body which boils at nearly $400^{\circ} \mathrm{C}$.

Dec. Io. - "On the effect of Heat on the Iodide of Silver," by G. F. Rodwell, F.C.S. Communicated by Prof. F. Guthrie, F.R.S.

The author endeavours to prove the following main facts :-

r. That the iodide of silver exists in three allotropic forms, viz. $(\alpha)$ at temperatures between $\times 16^{\circ} \mathrm{C}$. and its fusing-point, as a plastic, tenacious, amorphous substance, possessing a reduish colour, and transparent to light; $(\beta)$ at temperatures below $\Upsilon 16^{\circ} \mathrm{C}$. as a brittle, opaque, greenish-grey, crystalline mass ; and $(\gamma)$ if fused and poured into cold water, as an amorphous, very brittle, yellow, opaque substance.

2. That the iodide possesses a point of maximum density at or about $116^{\circ} \mathrm{C}$. at the moment before passing from the amorphous into the crystalline condition.

3. That if we allow a mass of molten iodide to cool, the fol 